\title{
AN ANALYSIS OF THE PUSH AND PULL FACTORS INFLUENCING
}

\section{THE ASPIRATIONS OF THE STUDENTS OF AGRICULTURE}

\section{SATHYA SHRI. K. $\mathbf{P}^{1} \&$ ARUNACHALAM. $\mathbf{R}^{2}$}

${ }^{1}$ Stduent, Department of Agricultural Extension and Rural Sociology, TNAU, Coimbatore, Tamil Nadu, India

${ }^{2}$ Professor, Department of Agricultural Extension and Rural Sociology, TNAU, Coimbatore, Tamil Nadu, India

\section{ABSTRACT}

The state agricultural universities under ICAR are offering wide varied agricultural education in India, apart from few central universities and conventional universities. Several studies confirm that the students' aspirations differ widely. There are several push and pull factors govern the aspirations of the students. The present study aimed to enumerate the push and pull factors governing the aspirations of the students of agriculture. The study was conducted among the students of all the constituent colleges of Tamil Nadu Agricultural University (TNAU). The sample size was 156 student respondents selected by employing the proportionate random sampling method. Data were collected using structured and standardized interview schedule. The study followed the ex-post facto research design. Percentage analysis was done to get a meaningful interpretation of the results. Family prestige, sibling status, clearing family debt and parents' choice were the major push factors. Job safety and security, potential to generate income (through selfemployment projects), higher salary and potential of the jobs to elevate family economic level were the major pull factors.

KEYWORDS: Aspiration, Push Factors, Pull Factors \& Students

Received: Mar 14, 2019; Accepted: Apr 04, 2019; Published: Apr 24, 2019; Paper Id.: IJASRJUN20198

\section{INTRODUCTION}

Agricultural students have some plans to settle down in specific career after getting the degree. They do aspire for a remunerative job as a fruit of their hard labours and have their own liking and disliking for various career avenues open to them after graduation. Students settle themselves in the available job in the fields such as department of agriculture, banking sector, fertilizer and pesticide companies. Students may also go for higher studies. Thus, there are various opportunities open to agricultural graduates, they can select any one of them as per their aspirations.

In every university, apart from the mandatory educational programmes there is a placement cell which takes concerted efforts for the better placement of the students. There are trained staff members, who guide and motivate the students to explore the best opportunities for their settlements. Despite all these systematic efforts there exist greater variations in the settlement pattern of the students, as some may not join in the jobs they get through campus interview and some prefer to go for higher education. Even in their aspiration of doing higher education their preferences on the choice of institutions varies from parent institute, national to international institutions.

Several studies confirm that agricultural students' job market include, State dept. of agriculture, Officers services through TNPSC, National UPSC, Nationalised and private banks, NGOs, Seed firms, Fertilizer industries, University and research organizations, ICAR - ARS services, starting up own agri-clinics, etc. There are various 
factors which governs the aspiration of students of agriculture. Some factors act as push factors, forcing the students towards some courses or jobs (or) higher educational aspirations are regarded as 'push' factors. There are certain factors associated with the nature of jobs / merits of the higher education which are called as 'pull' factors.In a study on role of push factors, Dunn et al.,(1994) highlighted the impact of siblings in designing the aspirations. The birth order of an individual also influenced his or her career choice. Similarly, Bromley (2004), in his study concerning influences and motivation on which students base their choice of career takes into account the variables of birth order and gender and the relative impact of a number of influences such as school teachers and parents on career choice. In addition, if explores student's motivations when considering their careers. Their study found that parents have a greater influence than teachers in the students' selection of a career. In the same line, Salami (2006) investigated the influence of family, individual differences and cultural factors in the choice of gender-dominated occupations among female students in some tertiary institutions. Hierarchical multiple regression statistical analysis employed revealed that family, individual differences and cultural factors were the good predictors of the choice of gender-dominated occupations of female students.

Knowing more about the push and pull factors governing the aspirations of the students and valuing and acting upon such information is a key strategy that any educational institution can adopt to improve student outcomes and the quality of the educational process generally.

Considering the facts discussed above, the present study has been conducted with the following specific objective

- To assess the push and pull factors pertaining to the aspirations of the students of agriculture.

\section{METHODOLOGY}

This study is focused to analysis the push and pull factors governing the aspirations of the students of agriculture. In accordance with the objectives of the study, the constituent colleges of Tamil Nadu Agricultural University offering B.Sc (Agriculture) degree programmes were purposively selected as TNAU is one of the prominent premier institutes offering a wide variety of courses in agriculture at UG and PG levels in south India. Further, in Tamil Nadu Agricultural University there are seven constituent colleges offering B.Sc (Agriculture) programme. All the seven constituent colleges of TNAU (Coimbatore, Madurai, Trichy, Killikulam, Thanjavur, Thiruvannamali, Pudukottai) were selected for the study purpose.

As regards the selection of the respondents, the outgoing students (2015-2019) batch was considered for the study as they might have already finalised their own aspirations.

Finally, it is understood that a total of 620 number of students have been enrolled in the B.Sc (Agri) programmes under the constituent colleges of TNAU. It has been decided to select 25 percent of the above population as sample for the study and hence the sample size has been fixed as 156 respondents.

By employing proportionate random sampling method the respondents from constituent the colleges were selected. Ex-post facto research design was used in this study, which will suit the objectives and the type of information needed. Percentage analysis has been adopted in this study for simple interpretation and comparison. Data were collected by employing structured and standardized interview schedule. 


\section{FINDINGS AND DISCUSSIONS}

The push and pull factors governing the aspirations of the students were enumerated through an open ended questionnaire. Finally, there were 17 push factors and 14 pull factors identified through this studied.

Table 1: Distribution of the Respondents According to the Push and Pull Factors Associated with their Aspirations $\left(\begin{array}{c}\mathrm{n}=156 \\ * \text { Multiple response }\end{array}\right)$

\begin{tabular}{|c|c|c|c|}
\hline S. No & Factors & Number & $\begin{array}{c}\text { Percentage } \\
(\%)\end{array}$ \\
\hline \multicolumn{4}{|c|}{ I. Push Factors } \\
\hline 1 & Parents' choice & 103 & 66.03 \\
\hline 2 & To settle well soon in remunerative jobs to clear family debt & 116 & 74.34 \\
\hline 3 & To safeguard family prestige for higher education & 75 & 89.74 \\
\hline 4 & Opting for higher education till getting suitable job & 75 & 48.07 \\
\hline 5 & Requirement of higher education in certain jobs & 79 & 50.64 \\
\hline 6 & Influenced by peer circle & 74 & 47.44 \\
\hline 7 & To get personal higher value out of higher education & 93 & 59.62 \\
\hline 8 & Sibling status ( birth order) to settle well soon & 128 & 82.05 \\
\hline 9 & Parents pressure for higher education & 56 & 35.89 \\
\hline 10 & Parents pressure to settle in seeking suitable job & 86 & 55.13 \\
\hline 11 & Influence of the teachers for higher education & 45 & 28.85 \\
\hline 12 & Gender plays a major role either for higher education or job aspiration & 52 & 33.33 \\
\hline 13 & Cultural factors on the gender dominated occupations & 54 & 34.62 \\
\hline 14 & Cultural factors on the social aspirations like marriages & 42 & 26.29 \\
\hline 15 & Economic conditions & 55 & 35.26 \\
\hline 16 & To settle in life as early as possible & 45 & 28.85 \\
\hline 17 & Personal interest in the job / higher education & 52 & 33.33 \\
\hline \multicolumn{4}{|c|}{ II. Pull Factors } \\
\hline 1 & Job safety/ security & 147 & 94.23 \\
\hline 2 & Novelty of the job & 25 & 16.03 \\
\hline 3 & Career growth opportunities & 97 & 62.18 \\
\hline 4 & Ease of the job & 76 & 48.72 \\
\hline 5 & Prestige values associated with the job & 50 & 32.11 \\
\hline 6 & Prestige value associated with the higher education & 134 & 85.89 \\
\hline 7 & Opportunities for fellowship grant in higher education & 89 & 57.05 \\
\hline 8 & Opportunities for overseas settlement & 85 & 54.49 \\
\hline 9 & Higher salary & 142 & 91.03 \\
\hline 10 & Higher job enrichments & 125 & 80.13 \\
\hline 11 & Self-pride and sense of satisfaction associated with community service & 95 & 60.89 \\
\hline 12 & $\begin{array}{l}\text { Potential to generate gainful employment opportunities to others (through } \\
\text { self-employment projects) }\end{array}$ & 82 & 52.56 \\
\hline 13 & Potential to generate income (through self-employment projects) & 145 & 92.95 \\
\hline 14 & Potential of the jobs to elevate family economic level & 142 & 91.03 \\
\hline
\end{tabular}

(Multiple Response)

\section{Push Factors Governing the Aspirations of the Respondents}

The results given in the Table 1 reveals that most of the respondents ( 89.74 per cent) felt that they opt higher education because of the family prestige values followed by 82.05 per cent of the respondents who stated that their birth order of being the first in their family forces them to settle well soon so as to support other family members to settle well. A vast majority of the respondents (74.34 per cent) opt to settle well soon in the enumerative jobs to clear their family debts. Further, the majority of the respondents (66.03 per cent) stated that their parent's choice is the prime factor in deciding their future aspirations. 
A higher personal value associated with higher education was a major push factor to select a right type of higher education for about sixty percentage of the respondents (59.62 per cent). The majority of the respondents (55.13 per cent) were pressurized by their parents to settle well in suitable job and 50.64 per cent of the respondents felt about the requirement of higher education to settle well in some good positions.

Almost an equal percentage of the respondents opt to do higher education till they get suitable jobs (48.07 per cent), followed by the influence given by peer circle ( 47.44 per cent) on their aspirations. Around one third of the respondents stated their parents pressure for higher education (35.89 per cent), poor economic conditions (35.26 per cent), the influence of cultural factors on the gender dominated occupation (34.62 per cent), their own personal interest in their job/higher education (33.33 per cent) and their own gender (33.33 per cent) as prominent push factors for their aspirations.

An equal percentage of the respondents (28.85 per cent) referred the influence of their parents for higher education and their own interest to settle in life as soon as possible. About one fourth of the respondents (26.29 per cent) mentioned the cultural obligations to settle well in married life.

From the above findings it could be concluded that the family prestige value, the choice of the parents, birth order and obligation to clear family debts were the prominent push factors identified in this study which are found governing the differential aspirations of the student respondents.

\section{Pull Factors Governing the Aspirations of the Respondents}

There were 14 different pull factors identified through this study.

The safety and security factors associated with the jobs have acted as prominent pull factors (94.33 per cent). The potential of the self-employment projects to generate higher income (92.95 per cent), high salary associated with job (91.03 per cent) and the potential of the job to elevate the family economic condition ( 91.03 per cent) were the important pull factors for the expressed aspirations of the respondents.

Most of the respondents expressed the prestige value associated with higher education (85.89 per cent) and the job based enrichments ( 80.13 per cent) as their other important pull factors, followed by 62.18 per cent of the respondents mentioned the associated career growth opportunities also.

A major proportion of the respondents (60.98 per cent) expressed that they are interested in doing community services for their own village, for which the reported that the self pride and sense of satisfaction associated with such activities have attracted them to do so. For their aspirations related with higher education, the opportunities for fellowship grant (57.05 per cent) and possibilities of settlement in overseas (54.49 per cent) acted as prominent pull factors.

Besides, little more than half of the respondents (52.56 per cent) stated that the potential of the self-employment projects to generate adequate employment opportunities for their own people acted as the pull factors to go for a right type of self-employment project.

The easy nature of the job (48.72 per cent), the prestige values associated with job (32.11 per cent) and the novelty of the job (60.03 per cent) were the other important pull factors enumerated through this study.

From the above findings, it could be concluded that the job safety and security, higher salary, job related enrichments, potential of the job to elevate gamily economic conditions, potential of the self-employment projects to generate adequate incomeand the prestige value associated with higher education were the prominent pull factors 
governing the differential aspirations of the student respondents.

\section{SUMMARY AND CONCLUSIONS}

From this study, it could be understood that there existed wide variations in push and pull factors governing the aspiration of the student respondents.

As regards the push factor family prestige value was considered as a major one to go for higher education, whereas the birth ordinal position (sibling status) influenced them to settle early in some suitable jobs. Factors such as getting personnel higher value, parents pressure, influence of teachers, family economic condition and their personnel interest were the major push factors deciding the higher educational aspiration of the students. The factors such as clearing family debts, sibling status, parents pressure, cultural factors (on gender dominated occupation) and family economic conditions were found to influence job related aspirations. Parents' choice, the influence of peer circle and their gender decided both higher education and career related aspirations.

With regard to pull factors for their choice of job, job safety/ security, higher income opportunity in jobs, opportunities for overseas settlement associated prestige values, the ease of the job and the novelty of the job and possibility for a career growth opportunity were the important pull factors. As regards their higher education, factors like prestige value associated with higher education and opportunities for fellowship grants were the important pull factors. A considerable proportion of the respondents opted to do community service for which associated self pride and sense of satisfaction were quoted as pull factors. About half of the respondents mentioned the potential of the self-employment projects to generate gainful employment opportunities as the key factor to go for right type self-employment projects.

From the above analysis, it could be understood that the students have very clear thoughts about the critical push and pull factors associated with their aspirations. Further, in most of the cases the role of teachers and parents are very much important in selecting the right type of future settlement pattern.

\section{REFERENCES}

1. Bromley, H, Kniveton (2004). The influences and motivations on which students base their choice of career. Journal of Research in Education, 72, 47-59. https://dspace./boro.ac.uk/../bitstream/..//kniveton-Research-ineducation.pdf

2. Varghese, R., Norman, T. S., \& Thavaraj, S. (2015). Perceived Stress and Self Efficacy among College Students: A Global Review. International Journal of Human Resource Management and Research, 5(3), 15-24.

3. Dunn, J., Slumkowski, C. \&Beardsall, L. (1994). Sibling relationships from the pre-school period through middle childhood and early adolescence. Development Psychology, 30 315-325. psycnet.apa.org/psycinfo/1994-36 979-001.

4. T. Geetha(2014). Politics of Science Education: Equity, Social Mobility and Marginalisation of Government School Students in India. IMPACT : IJRHAL, 2(4), 145-154

5. Salami, S.O. (2006). Influence of culture, family and individual differences on choice of gender-dominated occupations among female students in tertiary institutions. Women in Management Review, 22, (8), 650-665. 
